American Journal of Pharmaceutical Education 2021; 85 (2) Article 8080.

\title{
RESEARCH
}

\section{Determining the Entrepreneurial and Intrapreneurial Intentions of Student Pharmacists in Iran}

\author{
Fatemeh Mirzayeh Fashami, PharmD, DBA, ${ }^{\text {a }}$ Mona Nili, PhD, PharmD, MBA, MS, ${ }^{\text {b }}$ \\ Ali Vasheghani Farahani, PhD, PharmD, ${ }^{\mathrm{c}}$ Nazneen Shaikh, BPharm, ${ }^{\mathrm{b}}$ Nilanjana Dwibedi, PhD, MBA, \\ S. Suresh Madhavan, $\mathrm{PhD}, \mathrm{MBA}^{\mathrm{d}}$ \\ ${ }^{a}$ Mahan Business School, Tehran, Iran \\ ${ }^{\mathrm{b}}$ West Virginia University, School of Pharmacy, Morgantown, West Virginia \\ ${ }^{\mathrm{c}}$ University of Medical Science, Pharmaceutical Management and Economics Research Center, Tehran, Iran \\ ${ }^{\mathrm{d}}$ University of North Texas, System College of Pharmacy, Fort Worth, Texas \\ Submitted March 31, 2020; accepted October 28, 2020; published February 2021.
}

\begin{abstract}
Objective. To identify factors and entrepreneurial characteristics associated with entrepreneurial and intrapreneurial intentions among Doctor of Pharmacy (PharmD) students in Iran.

Methods. First, the Entrepreneurial-Intrapreneurial Pharmacist Questionnaire (EIPQ), which was developed in the United States, was translated from English to Persian. The paper-based Persian-EIPQ questionnaire was then tested in a convenience sample of student pharmacists enrolled in pharmacy schools in Iran. The entrepreneurial characteristics questionnaire was evaluated using exploratory factor analysis with varimax rotation. Internal consistency was examined using Cronbach alpha. The association of demographics and educational variables and entrepreneurial characteristics with entrepreneurial and intrapreneurial intentions was determined using a multiple linear regression model.

Results. A total of 504 surveys, $98.6 \%$ of the completed questionnaires received, were analyzed. A majority of the participants were female (75.8\%) and from 18 to 25 years old (92.2\%). Entrepreneurial intention had a positive and significant association with risk-taking propensity, leadership self-efficacy, autonomy, achievement motivation, and having an entrepreneur in the family. Intrapreneurial intention had a positive and significant association with risk-taking propensity, leadership self-efficacy, achievement motivation, people liking, attending a private school, and having an entrepreneur in the family. Conclusion. Based on the findings, student pharmacists with higher levels of risk-taking propensity, achievement motivation, leadership self-efficacy, autonomy, and people liking may be more likely to have greater levels of entrepreneurial and/or intrapreneurial intention.
\end{abstract}

Keywords: entrepreneurial intention, intrapreneurial intention, student pharmacists, entrepreneurial characteristics, Iran

\section{INTRODUCTION}

Iran is a Middle Eastern country with a population of more than 80 million people. ${ }^{1}$ Similar to other Middle Eastern countries, pharmacy is a popular and highly competitive major in Iranian universities. ${ }^{2}$ Acceptance to Iranian pharmacy schools depends solely on applicants' entrance examination scores. In Iran, 12th-grade students need to complete a comprehensive entrance examination for entrance into public and private universities (Konkur), much like college entrance examinations in the United States, to gain admission to higher education programs

Corresponding Author: Fatemeh Mirzayeh Fashami, Mahan Business School, Mirzaye Zeinali St., North Sohrevardi St., Tehran, Iran. Tel: 00989126303741. Email:

Fatemeh.mirzaei@sbmu.ac.ir including pharmacy schools. ${ }^{3}$ The six-year Doctor of Pharmacy (PharmD) program is taught in the Farsi language. Student pharmacists are required to take basic medical science courses during their first two years. At the end of the second year, all student pharmacists need to pass a comprehensive basic medical sciences examination. Upon successfully passing the examination, student pharmacists usually take courses such as pharmacology, clinical pharmacy, medicinal chemistry, pharmacognosy, biotechnology, poisoning control, quality control, and industrial pharmacy. ${ }^{4}$ During the fifth and sixth years of pharmacy school, students need to intern in different settings such as community pharmacies, hospital pharmacies, and pharmaceutical companies. ${ }^{4}$ All student pharmacists also need to defend a PharmD thesis as part of 


\section{American Journal of Pharmaceutical Education 2021; 85 (2) Article 8080.}

their graduation requirements. Upon graduation, all graduates are supposed to work, usually in underserved areas, for the Ministry of Health and Medical Education (MOHME). After two years of mandatory services for MOHME, the majority of pharmacy graduates prefer to work in community or hospital pharmacies. Less than $20 \%$ of pharmacy graduates favor other settings (eg, pharmaceutical industry, academia, and governmental organizations). ${ }^{4,5}$

Although the majority of pharmacy graduates choose to work in community pharmacies or hospital settings, one of the main problems facing the health care system in Iran is the shortage of pharmacies, particularly in underserved areas. In 2015, the number of pharmacies per 100,000 population was 13 , which is significantly lower than the average of 20 pharmacies per 100,000 population in other Middle Eastern countries. ${ }^{4}$ Because only pharmacists are legally eligible to get a license to establish a new pharmacy, in 2005 MOHME urged pharmacy schools to increase the number of students they recruited. ${ }^{6}$ In addition, MOHME makes it possible for newly graduated pharmacists to do their two-year mandatory service for MOHME by running a new pharmacy in an underserved area. Despite all these efforts, the problem of pharmacy shortage is still a major issue in Iran. ${ }^{7}$

Compounding the limited professional services found in community pharmacies, Iranian pharmacists seem reluctant to provide innovative pharmacy services in these locations. In Iran, some possible innovative services are medication management programs, nicotine cessation programs, and weight management programs. Having pharmacists provide these clinical services can prevent unnecessary patient visits to physicians and increase access to health care in under-served areas. ${ }^{8,9}$ However, Iranian graduates have reported a lack of interest in providing these new pharmacy services, although almost all of them have a PharmD degree and are trained to provide clinical pharmacy services in community pharmacy settings. ${ }^{7,10}$ Notably, one of the most important goals of pharmacy education in Iran is training students to provide pharmacy clinical services. However, Iranian pharmacists only perform their traditional roles (eg, dispensing) and usually are not inclined to provide innovative pharmacy services. ${ }^{11}$ Many reasons, such as lack of reimbursements for clinical pharmacy services, may be behind these problems.

Another possible reason for these challenges to the expansion of pharmacy services is that Iranian pharmacists may not have the entrepreneurial and intrapreneurial intentions necessary to establish a new pharmacy or provide innovative pharmacy services to patients. ${ }^{12}$ In the context of pharmacy, the entrepreneurial intention is defined as the intent to provide new pharmacy services by establishing a new pharmacy. Similar to entrepreneurship intention, intrapreneurship intention has the component of providing new pharmacy services. ${ }^{13}$ The only difference is that the place of providing these new services is an existing pharmacy. Previous studies suggested that people who have higher entrepreneurial and intrapreneurial intention levels may have a higher level of some personality characteristics, such as problem-solving, leadership self-efficacy, and achievement motivation. ${ }^{14}$

Given the salient roles of entrepreneurial and intrapreneurial intention in addressing some major issues facing the health care system in Iran, pharmacy schools need to take initiative to help to solve these problems. We identified two broad approaches to increase entrepreneurship and intrapreneurship intension among student pharmacists. The first solution is to recruit students with high levels of entrepreneurial personality characteristics into pharmacy programs. The second solution is to foster entrepreneurial personality characteristics as well as entrepreneurial and intrapreneurial intention during pharmacy school. For both solutions, the ability to assess entrepreneurial and intrapreneurial intentions and their related personality characteristics is important. The current literature lacks any studies examining entrepreneurial and intrapreneurial intentions among student pharmacists in Iran. In a recent study conducted in the United States, the Entrepreneurial-Intrapreneurial Pharmacist Questionnaire (EIPQ) was developed and validated for measuring entrepreneurial and intrapreneurial intention and their related personality characteristics. ${ }^{15}$ Because the Farsi version of EIPQ was not available, the objective of this study was to translate and assess the validity of EIPQ for measuring entrepreneurial and intrapreneurial intentions and their related personality characteristics among Iranian student pharmacists. This study also identified the factors associated with entrepreneurial and intrapreneurial intentions among student pharmacists in Iran.

\section{METHODS}

A cross-sectional study was designed to survey all the students in the fourth, fifth, and sixth (last) year of a PharmD program in all pharmacy universities in Tehran, the capital city of Iran. Among the five pharmacy schools, two of them were public (Tehran University of Medical Sciences [TUMS] and Shahid Beheshti University of Medical Sciences [SBMU]) and three were private (Islamic Azad University Tehran Medical Sciences [IAUTMS], The International campus of Tehran University of Medical Science [ITUMS] and the International campus of Shahid Beheshti University of Medical 


\section{American Journal of Pharmaceutical Education 2021; 85 (2) Article 8080.}

Table 1. Demographic Characteristics of Student Pharmacists in Iran and Their Association with Entrepreneurial and Intrapreneurial Intentions ${ }^{\mathrm{a}}(\mathrm{N}=497)$

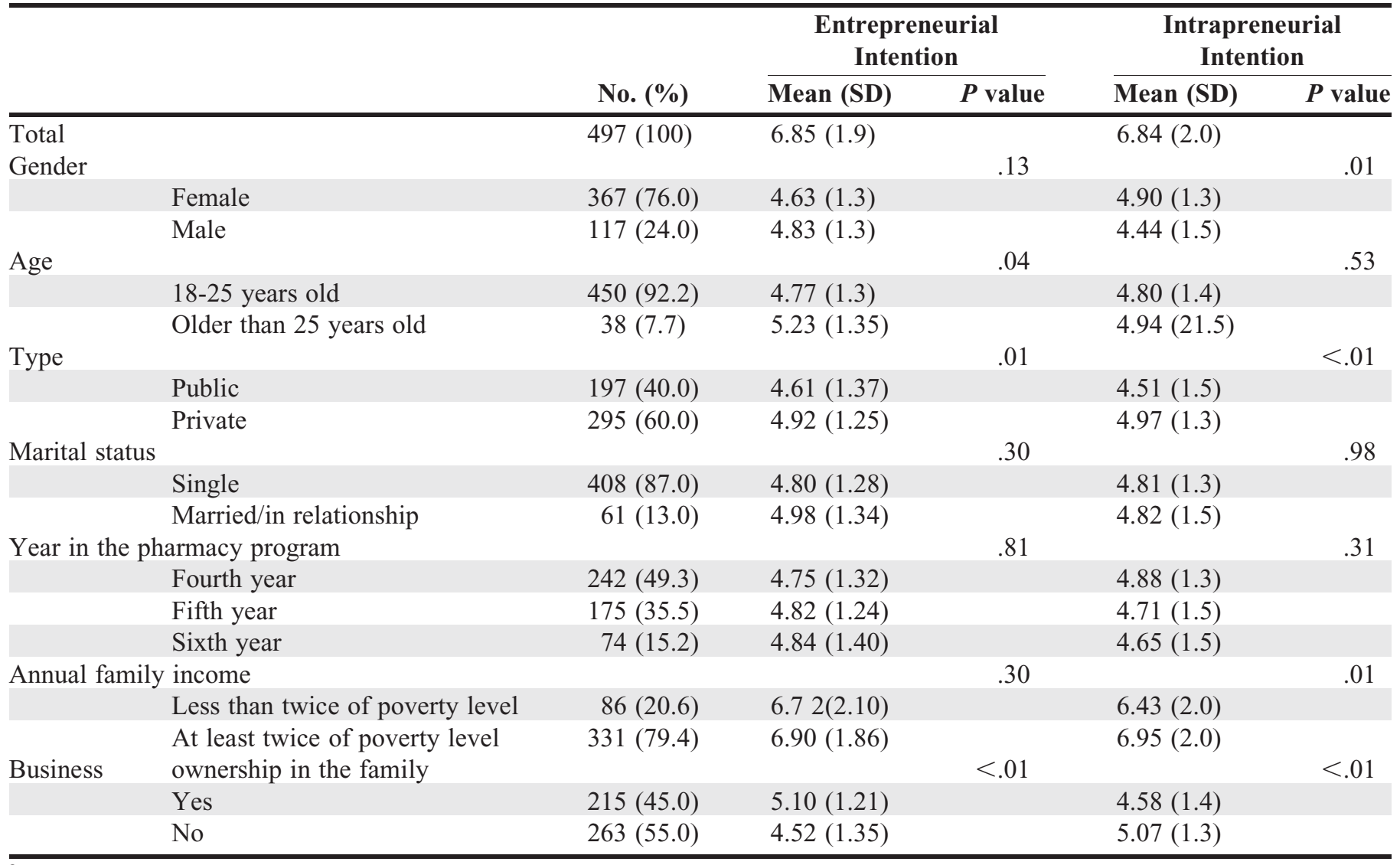

${ }^{a}$ Independent $t$ test was used for evaluating the association of all the factors with Entrepreneurial and Intrapreneurial intentions

Sciences [ISBMU]). The protocol of this study was evaluated and approved by the Ethics Committee at Shahid Beheshti University of Medical Science.

The EIPQ was used in this study. The EIPQ has been used and validated among student pharmacists in the United States. ${ }^{14,16}$ The 52-item EIPQ measures nine personality characteristics: locus of control (six items), innovativeness (three items), autonomy (five items), risktaking (three items), proactiveness (five items), achievement motivation (five items), people liking (seven items), problem-solving (six items), and leadership self-efficacy (12 items). ${ }^{17-24}$ Responses to all questions were rated on a seven-point Likert-based scale with responses ranging from $1=$ strongly disagree to $7=$ strongly agree.

As a Farsi version of the EIPQ was not available, this questionnaire was translated to Farsi based on best practice guidelines. ${ }^{25,26}$ In the first step, the questionnaire was translated independently by two bilingual translators to their native language, Farsi. After that, a third bilingual translator compared the original questionnaire with the translated Farsi versions of the questionnaire and prepared a new draft. This new draft was evaluated by a committee of experts to ensure face and content validity, and to prepare a pre-final draft of the EIPQ in Farsi. This committee decided to delete one of the questions for measuring entrepreneurial intention. After this step, the pre-final version of the questionnaire was back-translated to English by a bilingual interpreter who was a native English speaker and blind to the concept of the questionnaire. The back-translated version of the EIPQ was assessed and approved by the team that had originally developed the EIPQ. The pre-final version of the Farsi questionnaire was administered in a pilot test to 30 student pharmacists. After completing the questionnaire, the participants were verbally asked what each item meant to them. The construct validity and internal consistency reliability of the questionnaire were also assessed. The final draft of the questionnaire was prepared after making some minor language changes to the pre-final questionnaire. In addition to the items on the EIPQ, we also included some background questions to collect data on participants' gender, age, type of school, marital status, year in the pharmacy program, annual family income, and business ownership in the family. 


\section{American Journal of Pharmaceutical Education 2021; 85 (2) Article 8080.}

Table 2. Correlation of Personality Characteristics with the Entrepreneurial and Intrapreneurial Intentions of Student Pharmacists in Iran

\begin{tabular}{lcccr}
\hline & \multicolumn{2}{c}{ Entrepreneurial Intentions } & \multicolumn{2}{c}{ Intrapreneurial Intentions } \\
\cline { 2 - 5 } & $\boldsymbol{r}$ & $\boldsymbol{P}$ value & $\boldsymbol{r}$ & $\boldsymbol{P}$ value \\
\hline Intrapreneurial intentions. & 0.60 & $<.01$ & $\mathrm{NA}$ & $\mathrm{NA}$ \\
Locus of control & 0.12 & $<.01$ & 0.10 & .02 \\
Innovativeness & 0.24 & $<.01$ & 0.18 & $<.01$ \\
Autonomy & 0.32 & $<.01$ & 0.22 & $<.01$ \\
Risk Taking & 0.27 & $<.01$ & $<.19$ & $<.01$ \\
Proactiveness & 0.35 & $<.01$ & 0.27 & $<.01$ \\
Achievement motivation & 0.30 & $<.01$ & 0.28 & $<.01$ \\
People liking & 0.14 & $<.01$ & 0.22 & $<.01$ \\
Problem solving & 0.31 & $<.01$ & 0.24 & $<.01$ \\
Leadership self-efficacy & 0.42 & $<.01$ & & 0.41 \\
\hline
\end{tabular}

The class instructor announced that the survey would be conducted and then the questionnaire was administered to student pharmacists in the classroom or at an experiential setting. All data were collected in April and May 2019. All the students were assured of the anonymity and confidentiality of their responses. Participants voluntarily participated in the survey and filled out the paper questionnaire individually.

Descriptive statistics were used to describe the participants. Cronbach alpha was used to determine the internal consistency of the constructs, and an alpha Cronbach higher than 0.6 was considered acceptable. ${ }^{27}$ Exploratory factor analysis (EFA) with varimax rotation was utilized to assess construct validity. Based on EFA results, all parameters with factor loadings greater than 0.4 retained in the questionnaire. In EFA, the Kaiser-Meyer-Olkin (KMO) test was used to assess whether the sample size was adequate. The suggested acceptance threshold of KMO was $0.6 .^{26}$ In addition, the Bartlett test of sphericity was used to evaluate whether variables were related or suitable for structure detection. A significance level of less than .05 was considered acceptable for the Bartlett test. The association of personality characteristics and sociodemographic background factors with both entrepreneurial and intrapreneurial intentions were evaluated using the independent $t$ test.

Multiple-linear regression models were used to evaluate the adjusted association of personality characteristics with entrepreneurial and intrapreneurial intentions. The statistical significance level was set at $p<.05$. All data analysis was conducted in SPSS, version 23 (IBM, Chicago, IL).

\section{RESULTS}

In the pilot study of 30 student pharmacists, all the participants were 25 years and younger. The majority of them were female $(56.7 \%)$, single $(90.0 \%)$, in their sixth year of pharmacy school (83.3\%), and attended a public pharmacy school (80.0\%). In this sample, $33.3 \%$ of participants reported that they had at least one member in their extended family who owned a business. In the exploratory factor analysis, the factor loadings of all the items in the constructs were greater than 0.4 . For all of the constructs, the Cronbach alpha was greater than 0.6.

The finalized version of the questionnaire was administered to 504 participants. Of the 504 surveys, 497 were complete and analyzed. The majority of the participants were female $(74.0 \%), 25$ years old and younger (83.1\%), and single (81.7\%). The demographic characteristics of the students are shown in Table 1. Of all the participants, 198 (41.5\%) were from public universities, with 89 from SBMU and 109 from TUMS. The remainder of the 299 (59.5\%) participants came from private universities, with 10 from ISBMU, 71 from ITUMS, and 218 from IAUTMS. Almost half of the participants (49.3\%) were in their fourth year of the pharmacy program, $35.4 \%$ in the fifth year, and $15.1 \%$ in the sixth year. Of all the participants, $43 \%$ reported having a family member who owned a business.

The KMO Measure of Sampling Adequacy was greater than 0.6 for all the scales and acceptable for all the items, which was greater than the 0.6 cutoff deemed desirable. The Bartlett test of sphericity showed that the correlations were large enough to perform exploratory factor analysis. The factor loadings of all the items were greater than 0.4. The eigenvalues of the scales were greater than 1 . The Cronbach alpha of constructs ranged from 0.67 to 0.92 .

The unadjusted associations of background characteristics with entrepreneurial and intrapreneurial intention were evaluated (Table 1). Studying in a private school and having business owners in the family were significantly associated with both entrepreneurial and 


\section{American Journal of Pharmaceutical Education 2021; 85 (2) Article 8080.}

Table 3. Association Between Entrepreneurial Intention and Personal Characteristics of Student Pharmacists in Iran

\begin{tabular}{lccr}
\hline Construct & Adjusted Coefficient & $\mathbf{9 5}$ \% CI & $\boldsymbol{P}$ value \\
\hline Internal locus of control & -0.09 & $(-0.28-0.01)$ & .06 \\
Innovativeness & 0.03 & $(-0.07-0.13)$ & .59 \\
Autonomy & 0.15 & $(0.07-0.36)$ & $<.01$ \\
Risk-taking propensity & 0.15 & $(0.06-0.26)$ & $<.01$ \\
Pro-activeness & 0.05 & $(-0.10-0.28)$ & .36 \\
Achievement motivation & 0.13 & $(-0.05-0.31)$ & $<.01$ \\
People Liking & -0.00 & $(-0.03-0.11)$ & .93 \\
Problem Solving & 0.08 & $(0.11-0.46)$ & .14 \\
Leadership self-efficacy & 0.19 & $(-0.10-0.72)$ & $<.01$ \\
Female & 0.07 & $(-1.02-0.22)$ & .14 \\
Older than 25 years old & -0.06 & $(-0.16-0.57)$ & .21 \\
Private school & 0.05 & $(-0.36-0.67)$ & .28 \\
Single & 0.03 & $(-0.58-0.25)$ & .58 \\
Income at least twice of poverty level & -0.03 & $(0.18-0.87)$ & .44 \\
Having an entrepreneur among family members & 0.14 & & $<.01$ \\
\hline
\end{tabular}

$\mathrm{R}^{2}=.306, \mathrm{~F}(15,367)=10.8, p<.001$

Adjusted with age, sex, school type, marital status, annual family income, business ownership in the family, internal locus of control, innovativeness, autonomy, risk-taking propensity, pro-activeness, achievement motivation, people liking, problem solving and leadership self-efficacy

intrapreneurial intentions. Being more than 25 years old was significantly associated with entrepreneurial intention, and having an annual income above the poverty line was significantly correlated with intrapreneurial intention.

All the personality characteristics (ie, locus of control, innovativeness, autonomy, risk-taking propensity, proactiveness, achievement motivation, people liking, problem-solving, and leadership self-efficacy) had significant positive associations with both entrepreneurial and intrapreneurial intentions (Table 2).

Gender, having a business owner in the family, school type in terms of public or private, and personality characteristics were included in the adjusted regression models. The adjusted $\mathrm{R}^{2}$ value for the multiple linear regression model of entrepreneurial intention was 0.27 . The omnibus test for the model was significant $(p<.01)$, and the Durbin-Watson test rejected the existence of any selfcorrelation between independent variables (DurbinWatson statistics value $=1.8$ ). Entrepreneurial intention demonstrated positive and significant association with risk-taking propensity $(p<.01)$, leadership self-efficacy $(p<.01)$, autonomy $(p<.01)$, and achievement motivation $(p<.01)$. In addition, students who had a business owner in their family had a significantly $(p<.01)$ higher entrepreneurial intention (Table 3).

The multiple linear regression model of intrapreneurial intention had an adjusted $\mathrm{R}^{2}$ value of 0.21 . The ANOVA $\mathrm{F}$ omnibus result was significant $(p<.01)$, and the Durbin-Watson test did not show any self-correlation between independent variables (Durbin-Watson statistics value $=1.9$ ). Students having intrapreneurial intention was positively and significantly associated with risktaking propensity $(p=.01)$, leadership self-efficacy $(p<.01)$, achievement motivation $(p<.05)$, and people liking $(p<.05)$. Furthermore, students who attended private schools $(p<.05)$ and/or had a business owner in their family $(p<.05)$ were significantly associated with intrapreneurship intention (Table 4).

\section{DISCUSSION}

The Farsi version of the EIPQ is a valid and reliable instrument to measure entrepreneurial and intrapreneurial intention as well as entrepreneurial personality characteristics among Iranian student pharmacists. Pharmacy schools can use this questionnaire to select students with a higher likelihood of becoming an entrepreneur or intrapreneur pharmacist in the future. This questionnaire can be used as a tool to assess whether the pharmacy program is successful in improving entrepreneurial and intrapreneurial intention during six years of pharmacy school. Moreover, pharmacy school can use the finding of this study to foster entrepreneurial and intrapreneurial intention by nurturing and providing some personal training on required entrepreneurial characteristics such as risk-taking propensity, achievement motivation, and leadership.

Similar to previous studies in other countries, this study found an association between a student pharmacist having "risk-taking propensity" and having both entrepreneurial and intrapreneurial intentions. In a study conducted in Portugal, risk-taking propensity was found to be significantly associated with entrepreneurial intention 


\section{American Journal of Pharmaceutical Education 2021; 85 (2) Article 8080.}

Table 4. Association Between Intrapreneurial Intentions and Personal Characteristics of Student Pharmacists in Iran

\begin{tabular}{lccr}
\hline Construct & Adjusted Coefficient & $\mathbf{9 5}$ \% CI & $\boldsymbol{P}$ value \\
\hline Internal locus of control & -0.07 & $(-0.26-0.04)$ & .14 \\
Innovativeness & 0.02 & $(-0.09-0.13)$ & .72 \\
Autonomy & 0.09 & $(-0.21-0.28)$ & .09 \\
Risk-taking propensity & 0.16 & $(0.07-0.28)$ & $<.01$ \\
Pro-activeness & -0.01 & $(-0.20-0.20)$ & .98 \\
Achievement motivation & 0.11 & $(0.02-0.30)$ & $.02^{\mathrm{c}}$ \\
People Liking & 0.12 & $(0.03-0.27)$ & $.02^{\mathrm{b}}$ \\
Problem Solving & 0.02 & $(-0.11-0.17)$ & .69 \\
Leadership self-efficacy & 0.23 & $(0.17-0.54)$ & $<.01$ \\
Female & 0.06 & $(-0.15-0.71)$ & .20 \\
Older than 25 years old & -0.01 & $(-0.73-0.53)$ & .82 \\
Private school & 0.11 & $(0.05-0.81)$ & $<.05$ \\
Single & $<0.01$ & $(-0.54-0.52)$ & .97 \\
Income at least twice of poverty level & 0.05 & $(-0.20-0.69)$ & .28 \\
Having an entrepreneur among family members & 0.11 & $(0.05-0.78)$ & $<.05$ \\
\hline
\end{tabular}

$\mathrm{R}^{2}=.243, \mathrm{~F}(15,364)=9.1, p<.001$

Adjusted with age, sex, school type, marital status, annual family income, business ownership in the family, internal locus of control, innovativeness, autonomy, risk-taking propensity, pro-activeness, achievement motivation, people liking, problem solving and leadership self-efficacy

and the tendency toward business ownership. ${ }^{28}$ Moreover, in another study in Nigeria, personality characteristics were measured among student pharmacists, and risk-taking propensity was found to be significantly associated with entrepreneurial intention. ${ }^{29}$ In 2016, Rezvani and Ab Aziz evaluated personality characteristics among employees in Iran and found that risk-taking propensity has a significant and positive relation with intrapreneurial intention. ${ }^{30}$

Consistent with the literature, the current study found "achievement motivation" to be significantly associated with entrepreneurial and intrapreneurial intentions. Achievement motivation was found to be positively correlated with entrepreneurial intention in many studies. ${ }^{31-33}$ For example, achievement motivation was found to be one of the strongest predictors of entrepreneurship intention among student pharmacists in Nigeria. ${ }^{29}$ The findings of other studies also supported the association of achievement motivation with intrapreneurial intention. ${ }^{34,35}$ This study also found that leadership self-efficacy is associated significantly and positively with entrepreneurial intention as well as intrapreneurial intention. Similar to the findings of our study, a study conducted by Sheikh and colleagues in the United States also found a significant positive association of leadership self-efficacy with intrapreneurial intention among student pharmacists. ${ }^{15}$

In this study, a significant association between "people liking" and intrapreneurial intention was found. There are many studies available in the literature that support the association of people liking, or altruism, with intrapreneurship. ${ }^{35-37}$ Dress and colleagues suggested that social exchange can play an important role in this relationship. ${ }^{36}$ The finding is aligned with the findings of Sinha and Srivastava which showed that people liking has a significantly positive association with intrapreneurship intention, and work values can affect this association. ${ }^{35}$

Based on our findings, autonomy was significantly associated with entrepreneurial intention. Autonomy is defined as the liberty and independence to make decisions at work, and it pertains to independency in self-organization and self-regulation. ${ }^{38,39}$ Similar to the findings of our study, entrepreneurial intention had a significant association with autonomy in a sample of student pharmacists in the United States. Among master of business administration students, autonomy was associated with entrepreneurial intention. ${ }^{40}$

Another finding of this study was the association of "having a business owner in the extended family" with both entrepreneurial and intrapreneurial intentions. The nurturing that students who grow up in a family with an entrepreneurial background receive provides a special context that affects their future career intentions. ${ }^{41}$ Entrepreneur family members also can be the source of financial as well as nonfinancial assistance. ${ }^{42}$ Studies have shown that individuals with positive entrepreneur role models within their family are more motivated to start their own business. ${ }^{42,43} \mathrm{~A}$ study conducted on a sample of non-business major students in the United States also found that having a history of entrepreneurship is significantly associated with entrepreneurial intention. ${ }^{45}$ Based on the finding of this study, attending a private school has a positive association with intrapreneurial intention. The reason of this association is not clear and has not been evaluated in the literature. 


\section{American Journal of Pharmaceutical Education 2021; 85 (2) Article 8080.}

This study has several important limitations. The data were collected from student pharmacists in Tehran, Iran; thus, we may not be able to generalize the results to all student pharmacists in Iran. Another limitation is that students may have answered the questions in what they believed was a more professionally acceptable way. Furthermore, student pharmacists may have selected the most extreme responses because a Likert scale was used in the questionnaire. Finally, although we evaluated the most important personality characteristics that have been reported in the literature to be associated with entrepreneurism and intrapreneurism, there may be other personality characteristics that are associated with entrepreneurial or intrapreneurial intentions.

\section{CONCLUSION}

The Farsi version of the Entrepreneurial-Intrapreneurial Pharmacist Questionnaire was shown to be a valid and reliable instrument to measure entrepreneurial and intrapreneurial intention as well as entrepreneurial personality characteristics among Iranian student pharmacists. Three personality characteristics (ie, risk-taking propensity, achievement motivation, and leadership selfefficacy) and students having at least one business owner in their extended family were found to be significantly associated with both entrepreneurial and intrapreneurial intention. While "people liking" and "attending in private school" had a significant association with intrapreneurial intention, "autonomy" had a significant association with entrepreneurial intention. These findings can help pharmacy schools to put more emphasis on determining personality characteristics of student pharmacists to nurture and train them to become entrepreneurs and intrapreneurs. However, more studies may be needed to further validate relationships between personality characteristics and entrepreneurial or intrapreneurial intentions and student pharmacists eventually becoming entrepreneurs and intrapreneurs in Iran.

\section{REFERENCES}

1. Islamic Republic of Iran. International Bank for Reconstruction and Development. https://www.worldbank.org/en/country/iran/ overview. Accessed January 23, 2021.

2. Kheir N, Zaidan M, Younes H, Hajj E, Hajj ME, Wilbur K, Jewesson PJ. Pharmacy education and practice in 13 Middle Eastern countries. Am J Pharm Educ. 2008;72(6). doi:10.5688/aj7206133

3. Kamyab S. The university entrance exam crisis in Iran. Int High Educ. 2015;(51):22-23. doi:10.6017/ihe.2008.51.8010

4. Morteza-semnani K, Saeedi M. Pharmacy education in Iran. Pharm Educ. 2003;3(2):1-5. doi:10.1080/1560221031000147566 5. Eslami K, Kheiry O, Kouti L, Izadpanah M. Comparison of Iran's and world's leading faculties approved curriculum in the field of pharmacy, in terms of pharmaceutical care education. J Pha. 2016:58-63.
6. Hashemi-meshkini A, Keshavarz K, Nikfar S, Vazirian I, Kebriaeezadeha A. Pharmacists remuneration models in Iran and selected countries: a comparative study. Iran J Pharm Res. 2013; 12(4):955-964. doi:10.22037/ijpr.2013.1410

7. Zaboli P, Hashemi-Meshkini A, Varmaghani M, et al.

Pharmaceutical laws and regulations in Iran: an overview. J Res Pharm Pract. 2016;5(3):155. doi:10.4103/2279-042x.185709

8. Schifano F. Prescribing in mental health. In: Non-Medical Prescribing. London: Pharmaceutical Press; 2009:193-205. doi: 10.1017/CBO9781107415324.004

9. Van KK. Emergency contraceptive pills: dispensing practices, knowledge and attitudes of South Dakota pharmacists. Perspect Sex Reprod Health. 2005;37(1):19-24. doi:10.1111/j.1931-

2393.2005.tb00037.x

10. Mehralian G, Rangchian M, Javadi A, Peiravian F. Investigation on barriers to pharmaceutical care in community pharmacies: a structural equation model. Int J Clin Pharm. 2014;36(5):1087-1094. doi:10.1007/s1 1096-014-9998-6

11. Jahangard-rafsanjani Z, Sarayani A, Javadi M, Hadjibabaie M. Pharmacists' attitudes and perceived barriers about community pharmacy-based cardiovascular risk screening services. $J$ Pharm Care. 2014;2(4):142-148.

12. Peymani $P$. The need for revision of employment requirement of young pharmacists. Iranian Students' News Agency. https:// www.isna.ir/news/96052817000/. Accessed January 23, 2021. 13. Hohmeier KC, Gatwood J. Toward intrapreneurship in pharmacy education. Am J Pharm Educ. 2016;80(3). doi:10.5688/ajpe80353 14. Shaikh NF, Nili M, Dwibedi N, Madhavan SS. Measuring entrepreneurial and intrapreneurial intentions in student pharmacists. Am J Pharm Educ. 2019;83(10). doi:10.5688/ajpe7233

15. Wiethe-Körprich, Michaela SW, Bley S, Kreuzer C. Intrapreneurship competence as a manifestation of work agency: a systematic literature review. Agency at work. 2017:37-65. doi: 10.1007/978-3-319-60943-0

16. Nili M, Shaikh NF, Dwibedi N, Madhavan SS. Association of entrepreneurial traits with interest in becoming a pharmacist provider among student pharmacists. J Pharm Pract. 2019:1-6. doi:10.1177/ 0897190019882874

17. Mueller SL, Thomas AS. Culture and entrepreneurial potential: a nine country study of locus of control and innovativeness. J Bus Ventur. 2001;16(1):51-75. doi:10.1016/S0883-9026(99)00039-7 18. Van Gelderen M, Brand M, Van Praag M, Bodewes W, Poutsma E, Van Gils A. Explaining entrepreneurial intentions by means of the theory of planned behaviour. Career Dev Int. 2008;13(6):538-559. doi:10.1108/13620430810901688

19. Gomez-Mejila LR, Balkin DB. Effectiveness of individual and aggregate compensation strategies. Ind Relations A J Econ Soc. 1989; 28(3):431-445. doi:10.1111/j.1468-232X.1989.tb00736.x 20. Bateman TS, Crant JM. The proactive component of organizational behavior: a measure and correlates: Summary. $J$ Organ Behav. 1993;14(2):103-118. doi:10.1002/job.4030140202 21. Robinson GFWB, Switzer GE, Cohen ED, et al. Special reports shortening the work preference inventory for use with physician scientists: WPI-10. Clin Transl Sci. 2014;7(4). doi:10.1111/cts.12132 22. Filsinger EE. A measure of interpersonal orientation: the linking people scale. J Pers Assess. 1981;45(3):295-300. doi:10.1207/ s15327752jpa4503

23. Heppner PP, Petersen CH. The development and implications of a personal problem-solving inventory. J Couns Psychol. 1982;29(1): 66-75. doi:10.1037/0022-0167.29.1.66 


\section{American Journal of Pharmaceutical Education 2021; 85 (2) Article 8080.}

24. Bobbio A, Manganelli AM. Leadership self-efficacy scale: a new multidimensional instrument. TPM-Testing, Psychom Methodol Appl Psychol. 2019;16(1):3-24.

25. Beaton DE, Bombardier C, Guillemin F, Ferraz MB. Guidelines for the process of cross-cultural adaptation of self-report measures. Spine. 2000;25(24):3186-3191. doi: 10.1097/00007632-20001215000014

26. Tsang S, Royse CF, Terkawi AS. Guidelines for developing, translating, and validating a questionnaire in perioperative and pain medicine. Saudi J Anaesth. 2019;11(Suppl 1):1-15. doi:10.4103/ sja.SJA_203_17

27. Khursheed A, Mustafa F, Fatima M, Siddique F. Entrepreneurial intentions: gem-based emipirical analysis on the northern Europe and Asian countries. Int J Entrep Knowl. 2019;6(2):59-70. doi:10.2478/ ijek-2018-0014

28. Teixeira A. Entrepreneurial potential in chemistry and pharmacy. Results from a large survey. J Bus Chem. 2008;5(2).

29. Afolabi M, Ola-Olorun O, Abereijo I, Uchegbu V. Assessment of entrepreneurial traits and intention of pharmacy students in Obafemi Awolowo University, Ile-Ife, Nigeria. Br J Pharm Res. 2016;10(2): 1-11. doi:10.9734/bjpr/2016/22855

30. Douglas EJ, Fitzsimmons JR. Intrapreneurial intentions versus entrepreneurial intentions: Distinct constructs with different antecedents. Small Bus Econ. 2013;41(1):115-132. doi:10.1007/ s11187-012-9419-y 31. Karabulut AT. Personality traits on entrepreneurial intention. Procedia - Soc Behav Sci. 2016;229:12-21. doi:10.1016/ j.sbspro.2016.07.109

32. Rauch A, Frese M. Let's put the person back into entrepreneurship research: a meta-analysis on the relationship between business owners' personality traits, business creation, and success. Eur J Work Organ Psychol. 2007;16(4):353-385. doi: 10.1080/13594320701595438 33. Popescu CC, Bostan I, Robu IB, Maxim A, Diaconu L. An analysis of the determinants of entrepreneurial intentions among students: a Romanian case study. Sustain. 2016;8(8):1-22. doi: $10.3390 /$ su8080771
34. Jain R, Ali SW. Entrepreneurial and intrapreneurial orientation in Indian enterprises: an empirical study. South Asian J Manag. 2012; 19(3).

35. Sinha N, Srivastava KB. Association of personality, work values and socio-cultural factors with intrapreneurial orientation. $J$ Entrep. 2015;22(1):91-113. doi:10.1177/0971355712469186

36. Dess GG, Ireland RD, Zahra SA, Floyd SW, Janney JJ, Lane PJ. Emerging issues in corporate entrepreneurship. J Manage. 2003; 29(3):351-378. doi:10.1016/S0149-2063

37. Hemingway CA. Corporate social entrepreneurship: integrity within. In: Encyclopedia of Corporate Social Responsibility. Berlin, Heidelberg: Springer; 2013:546-553. doi:10.1007/978-3-642-280368

38. Lumpkin GT, Cogliser CC, Schneider DR. Understanding and measuring autonomy: an entrepreneurial orientation perspective. Entrep Theory Pract. 2009;33(1):47-69. doi:10.1111/j.15406520.2008.00280.x

39. Baluku MM, Leonsio M, Bantu E, Otto K. The impact of autonomy on the relationship between mentoring and entrepreneurial intentions among youth in Germany, Kenya, and Uganda. Int $J$ Entrep Behav Res. 2019;25(2):170-192. doi:10.1108/IJEBR-102017-0373

40. Douglas EJ, Fitzsimmons JR. Entrepreneurial intentions towards individual vs. corporate entrepreneurship. In: SEAANZ 2005 Conference, Armidale, NSW. 2005:25-30.

41. Zellweger T, Sieger P, Halter F. Should I stay or should I go? Career choice intentions of students with family business background. J Bus Ventur. 2010;26(5):521-536. doi:10.1016/ j.jbusvent.2010.04.001

42. Carr JC, Sequeira JM. Prior family business exposure as intergenerational influence and entrepreneurial intent: a theory of planned behavior approach. J Bus Res. 2007;60(10):1090-1098. doi: 10.1016/j.jbusres.2006.12.016

43. Kolvereid L. Prediction of employment status choice intentions. Entrep Theory Pract. 1996;21(1):47-58. doi:10.1177/ 104225879602100104

44. Frazier Barbara J, Niehm LS. Predicting the entrepreneurial intentions of non-business majors: a preliminary investigation. In: USASBE/SBI Conference. Tucson, AZ, January 2006:14-17. 
American Journal of Pharmaceutical Education 2021; 85 (2) Article 8080.

Appendix 1. Summary of Items in Each Construct and Their Relevance

\begin{tabular}{|c|c|c|c|c|}
\hline \multirow[b]{2}{*}{ Construct } & \multirow[b]{2}{*}{ Items } & \multicolumn{2}{|c|}{ Current Study in Iran } & \multirow{2}{*}{$\frac{\text { Study in the U.S. }}{\alpha}$} \\
\hline & & Factor Loading & $\bar{\alpha}$ & \\
\hline \multirow[t]{3}{*}{ Entrepreneurship } & $\begin{array}{l}\text { Having intention to start a self-owned business } \\
\text { in } 2 \text { years }\end{array}$ & .70 & .76 & .91 \\
\hline & $\begin{array}{l}\text { Having intention to start a self-owned business } \\
\text { to provide radical innovation }\end{array}$ & .88 & & \\
\hline & $\begin{array}{l}\text { Having intention to start a self-owned business } \\
\text { to introduce a new variant of existing service }\end{array}$ & .88 & & \\
\hline \multirow[t]{3}{*}{ Intrapreneurship } & $\begin{array}{l}\text { Having intention to manage a division in an } \\
\text { existing firm to }\end{array}$ & .89 & .91 & .95 \\
\hline & $\begin{array}{l}\text { provide a radical innovation Having intention to } \\
\text { manage a division in an existing firm to }\end{array}$ & .94 & & \\
\hline & $\begin{array}{l}\text { provide a new service Having intention to } \\
\text { manage a division in an existing firm to } \\
\text { provide a to target a new market }\end{array}$ & .92 & & \\
\hline \multirow{4}{*}{ Internal locus of control } & Belief in gaining achievements due to luck (-) & .72 & & \\
\hline & Belief in actions will determine the life & .67 & & \\
\hline & Belief in being successful due to hard work & .63 & & \\
\hline & Belief in being able to control the life & .63 & & \\
\hline \multirow[t]{3}{*}{ Innovativeness } & Have novel ideas & .86 & .85 & .82 \\
\hline & Participation in creative activities & .90 & & \\
\hline & Not being creative $(-)$ & .86 & & \\
\hline \multirow[t]{2}{*}{ Autonomy } & Preference of making decision by him/herself & .70 & .77 & .72 \\
\hline & Ability to regulate his/her time & .76 & & \\
\hline \multirow{4}{*}{ Proactiveness } & Belief in being able to make possible & .74 & & \\
\hline & Excel at identifying opportunities & .69 & & \\
\hline & Looking for better ways & .70 & & \\
\hline & Belief in nothing can stop me from my idea & .72 & & \\
\hline \multirow[t]{5}{*}{ Achievement motivation } & Motivated by the recognition from other people & .76 & .68 & .71 \\
\hline & $\begin{array}{l}\text { Showing other people my good performance at } \\
\text { work }\end{array}$ & .77 & & \\
\hline & $\begin{array}{l}\text { Belief in success means doing better than other } \\
\text { people }\end{array}$ & .66 & & \\
\hline & Having personal promotion goals & .59 & & \\
\hline & Having personal income goals & .51 & & \\
\hline
\end{tabular}

(Continued) 
American Journal of Pharmaceutical Education 2021; 85 (2) Article 8080.

(Continued)

\begin{tabular}{|c|c|c|c|c|}
\hline \multirow[b]{2}{*}{ Construct } & \multirow[b]{2}{*}{ Items } & \multicolumn{2}{|c|}{ Current Study in Iran } & \multirow{2}{*}{$\frac{\text { Study in the U.S. }}{\alpha}$} \\
\hline & & Factor Loading & $\alpha$ & \\
\hline \multirow[t]{5}{*}{ People liking } & $\begin{array}{l}\text { Having the happiest experiences with other } \\
\text { people }\end{array}$ & .56 & .73 & .83 \\
\hline & $\begin{array}{l}\text { Belief in people are not important for my } \\
\text { happiness (-) }\end{array}$ & .56 & & \\
\hline & Preference to have company of other people & .65 & & \\
\hline & Tendency to like only close friends (-) & .65 & & \\
\hline & $\begin{array}{l}\text { Belief in the importance of other people in } \\
\text { personal life }\end{array}$ & .67 & & \\
\hline \multirow[t]{3}{*}{ Problem solving } & Tendency to enjoy tackling new problems & .66 & .82 & .79 \\
\hline & Tendency to enjoy solving complex problems & .60 & & \\
\hline & Being able to act decisively in problem solving & .81 & & \\
\hline \multirow[t]{8}{*}{ Leadership self-efficacy } & $\begin{array}{l}\text { Being able to establish very good relationships } \\
\text { with colleagues }\end{array}$ & .65 & .92 & .90 \\
\hline & $\begin{array}{l}\text { Being able to go straight to the heart of the } \\
\text { matter }\end{array}$ & .57 & & \\
\hline & $\begin{array}{l}\text { Being able to successfully manage relationships } \\
\text { with group members }\end{array}$ & .70 & & \\
\hline & Being confident in ability to get things done & .68 & & \\
\hline & $\begin{array}{l}\text { Being able to help group members to reach the } \\
\text { group's targets }\end{array}$ & .73 & & \\
\hline & $\begin{array}{l}\text { Being able to make the people to appreciate } \\
\text { him/her }\end{array}$ & .69 & & \\
\hline & $\begin{array}{l}\text { Being able to gain the consensus of group } \\
\text { members }\end{array}$ & .77 & & \\
\hline & $\begin{array}{l}\text { Being able to lead a group with the consensus of } \\
\text { all members }\end{array}$ & .77 & & \\
\hline
\end{tabular}

$\alpha$ : Cronbach alpha, (-)=Negative item 